level. Pilgrims usually walk about the busy streets of Valetta, making purchases to take home with them, either in the afternoon, or in a day or two. All this would take place more than three-quarters of a mile from the plague hospital, and separated from it by the harboux (1100 or 1200 yards of water). The hospital stands on an island. No connexion was ever traced, or, so far as came out on the inquiry, even suspected, between these pilgrims and subsequent cases of cholera in Valetta itself.

All the pilgrims were in good health. They had no communication with the plague hospital; and they had left Valetta for their homes at a time when only one pilgrim returning from Mecca had been seized with cholera, and that was in a camp in Egypt. As already stated, the first case, in a soldier's child in the plague hospital, took place nearly three weeks after they were gone.

One word more. The writer of the notice accuses me of either not knowing or ignoring what others had done in the scientific investigation of cholera. But the first pages of the reports show that my inquiry was purely a practical one, for ascertaining local causes of disease. I had no authority to enter into these questions, and my only reason for noticing any points regarding the importation and spread of cholera was what I have stated in the report-namely, that certain views on these subjects held in Malta were most adverse to sanitary improvement. All I have done is simply to bring these importation cases to the test of facts, and I have distinctly stated that the results neither affirmed nor disproved the communicability of cholera. In as far as regards my not having used the information furnished by the Cholera Conference, the writer of the notice could not know that the inquiry at Malta and Gibraltar was in progress before the Cholera Conference was in existence, and that it was by mere accident that both of my reports were not printed before the Conference report was agreed to. The imperfect previous information about the epidemic was what the authorities in Malta had to guide them at the time; and I have little doubt that their present information regarding affected countries is not a whit more satisfactory. What we really require in dealing with epidemics is what I have suggested-namely, an "account current" of the public health in countries where epidemics originate, and not ex post facto information.

$$
\begin{aligned}
& \text { I am, Sir, your obedient servant, } \\
& \text { Sept. 9th, 1867. JoHx SUTHERLAND. }
\end{aligned}
$$

\section{LONDON HOSPITAL GRIEVANCES.}

\section{To the Editor of The Lancet.}

Sin,-_In your leading article of this day you charge me with having promised "to do all I could" for the successful candidatie in a recent election. During my twenty years of office I have carefully avoided making any promise whatever to any candidate, and I have as carefully abstained from any partisanship whatever. The occurrence to which you refer was therefore simply impossible, and the assertion incorrect.

The smart paragraphs in which you have seen fit to indulge, with a view to raise a laugh at my expense, will no doub amuse such of your readers as are not personally acquainted with me, and, I think, will equally disgust those who are. I leave them, therefore, without further notice, to perform their allotted task.

Sept. 7th, 1867.

$$
\text { I am, Sir, your most obedient servant, }
$$
WM. J. NIXON.

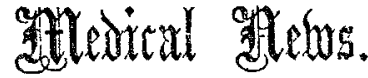

Apothecaries' Hall. - The following gentlemen passed their examination in the Science and Practice of Medicine, and received certificates to practise, on Sept. 5th :Anderson, Robert, St. George's Hospital.

Biiling, James Pymar, Apsley-place, Glasgow.

Johnson, Richard Locke, Charrington-street, Oakleg-square.

Jones, Robert William, High-street, Poplar.

Little, Edward Moore, Shaw Melksham, Wilts.

Ridley, Joseph Simpson, Preston

The following gentlemen passed on Sept. 12th :-

Braye, Hardwick Hubert, Wellington-square, Hastings. Cornish, Edgcumbe, Tavistock, Devon.

Cornish, Edgeumbe, Tavistock, Devon.

Eddowes, Arthnr Benjamin Jackson, Loughborough.
Howells, Thomas, Royal London Ophthalmic Hospital.

Howells, Thomas, Royal London ophthalmic Hos

Kemp, William George, Canterbury, Kent.
And on the last-mentioned day the following gentlemen passed their first examination:-

Edward Forbes Gaitskell and Richard Bowen Hingg, of Guy's Hospital ; Franeis de Havilland Hall, St. Bartholomew's Hospital.

IN Berlin, the policemen of all railway and police stations, and of the market places, have been furnished with galactometers, in order to put a stop to the adulteration of the milk, which is practised there on a great scale.

According to a report from Vienna, in that city, during the last year, 12,943 legitimate, and 13,802 illegitimate, children have been born.

Grorge Wiruis, M.D., and Justice of the Peace for the borough of Monmouth, has been appointed by the Lord Chancellor a magistrate for the county of Monmouth.

London HospiTAL. - The operation of Ligature of the Common Iliac Artery is expected to take place this day (Saturday), by Mr. Maunder, at 2 P.M.

The German Congress of Naturalists and Physicians, which meets every year in one of the larger towns of Germany, was opened, on the 18th inst., at Frankfort-on-the-Maine. There has, this year, been established a new section for public health, the members of which are not only medical men but also chemists, meteorologists, engineers, officials, and laymen. The topics this year to be discussed are :-(1), Etiology of typhus fever; (2), drainage; (3), the high rate of mortality amongst children.

Representation of the University of London.m. An influential meeting was held in the committee room of Section D of the British Association at Dundee to further the election of Sir John Lubbock. Among those present were-Sir W. Thomson, President of Mathematical and Physical Section; Dr. Sharpey, President of the Section of Anatumy and Physiology; Prof. Busk, President of the Section of Zoology and Botany ; Prof. Wheatstone, Prof. Sylvester, Prof. Tyndall, Prof. Allen Thon:son, Prof. Ansted, Dr. Williamson, Mr. Gassiot, Prof. Hirst, Dr. Odling, Prof. Turner, Prof. M. Foster, Prof. G. C. Foster, Dr. A. C. Brown, \&c. Professor Tyndall was in the chair; and it was proposed by Sir William Thomson, and seconded by Professor Williamson, and carried unanimously :- "That Sir John Lubbock, Eart., having been brought forward by an influential party among the graduates of the University of London, and an opportunity being thereby afforded of obtaining for science a representative in the House of Commons, it is highly desirable that those who are interested in science should do all in their power to assist in securing his election." Without ex r ressing an opinion as to Sir John Lubbock's fitness to represent the London University, we question the propriety of using the meeting of the British Association in this way.

The Medico-Chirurgical, Society of Glasgow.At the meeting of this Society, held on the 6th inst., in the Hall of the Faculty of Physicians and Surgeons, St. Vincentstreet, the following gentlemen were elected office-bearers for the present session:-President: Dr. Allen Thomson. VicePresidents : Dr. Coats, Dr. W. T. Gairdner. Council : Dr. Yeaman, Mr. Robertson (Renfrew), Dr. Dewar, Dr. Tindal, Dr. G. H. B. Macleod, Dr. A. R. Simpson, Dr. F. H. Thomson, Dr. Richmond (Paisley). Secretaries : Dr. James Adams, Dr. Robert Perry. Treasurer: Dr. H. R. Howatt.

\section{MEDICAL VACANCIES.}

Birmingham Lying-in Hospital-Resident Surzen.

Carmarthenshire \&c. Joint Lunatic Asylum-Medical Superintendent Dorset County Hospital-House-Surgeon, vice Mr. Bennett, deceased. The Royal Hospital for Diseases of the Chest-Two Physicians, vice Dr. Riehardson and Dr. Leared, resigned.

West Ham Dispensary-House-Surgeon and Dispenser.

Western General Dispensary-Physician in Ordinary.

\section{MEDICAL APPOINTMENTS.}

J. E. Bennext, M.D., has been appointed Medical Officer and Public Vaceinator for District No. 4 of the Frome Union, Sumersetshire, vice Wm. Croome, M.R.C.S.E., resigned.

Surg.-Major Dome NICHETy, M.D., 75th Regt., has been appointed Principal Medical and Satitary Officer at Gibraltar, vice I/r. Wm. Rutherford, C.B. M.I.G., who has proceeded on le ve; Assist.-Surg. Murphy, L.M.C.P.L. 75th Regt., has been appointed to take medi'" I char ce of his Regiment,

J. Fox, M.R.C.S. E., has been appointed Consultivg Surgen to the Dorset County and Weymouth Royal Eye Iufirmary, on resigning as Surgeon. J. C. GaRMAN, M.R.C.P.L., M.R.C.S.E., has been app inited Medical Office of Health for Wednesbary, vice H. E. Prnetor, L. R.C.P Ed., deveased. No. 2 of the Wetherby Union, vice J. Wood, M D, resigned. 